\title{
Skeletal Development and Mineralization Pattern of the Vertebral Column, Dorsal, Anal and Caudal Fin Complex in Seriola Rivoliana (Valenciennes, 1833) Larvae
}

\author{
Mesa-Rodríguez A*, Hernández-Cruz CM, Socorro JA, Fernández-Palacios H, Izquierdo MS and Roo J
}

Aquaculture Research Group, Science and Technology Park, University of Las Palmas de Gran Canaria, P. O. Box 56, 35200 Telde, Canary Islands, Spain

\begin{abstract}
Bone and fins development in Seriola rivoliana were studied from cleared and stained specimens from 3 to 33 days after hatching. The vertebral column began to mineralize in the neural arches at $4.40 \pm 0.14 \mathrm{~mm}$ Standard Length (SL), continued with the haemal arches and centrums following a cranial-caudal direction. Mineralization of the caudal fin structures started with the caudal rays by $5.12 \pm 0.11 \mathrm{~mm} \mathrm{SL}$, at the same time that the notochord flexion occurs. The first dorsal and anal fin structures were the hard spines (S), and lepidotrichium (R) by $8.01 \pm 0.26$ $\mathrm{mm} \mathrm{SL}$. The metamorphosis was completed by $11.82 \pm 0.4 \mathrm{~mm} \mathrm{SL}$. Finally, the fin supports (pterygiophores) and the caudal fins were completely mineralized by $16.1 \pm 0.89 \mathrm{~mm} \mathrm{SL}$. In addition, the meristic data of 23 structures were provided. Results from the present study might be used as a practical guide for future studies on this field with $S$. rivoliana or in related species.
\end{abstract}

Keywords: Amberjack; Hatchery; Abnormalities; Osteology; Skeleton

\section{Introduction}

Longfin yellowtail, Seriola rivoliana (Valenciennes, 1833) is one of the species proposed for marine aquaculture diversification, mostly due to its fast growth rate $[1,2]$ and worldwide distribution. This species belongs to Carangidae family, along with other popular species like Seriola dumerili (greater amberjack), Seriola lalandi (yellowtail king fish) and Seriola quinqueradiata (Japanese yellowtail). Even though $S$. rivoliana is commercially produced [3], studies about its biology are scarce and only few reports on larval rearing have been conducted in Ecuador [4-6], Hawaii [7] and more recently in the Canary Islands [8]. In contrast, numerous studies of the genus Seriola have been published related to the feeding requirements and nutrition [9-17], reproduction biology [2,18-21] and culture needs [8,22-26].

Regarding osteology studies, previous reports illustrate the bone structure development for other Seriola species. The osteological development of the greater amberjack have been described by different authors [27,28] These authors obtained distinct results probably associated to different environmental conditions and/or the number of samples. Also, the caudal skeleton development of the S. lalandi has been reported [29]. In addition, numerous studies have described the osteological development of other marine finfish species, such as Sparus aurata [30,31], Pagrus pagrus [32,33], Solea senegalensis [34,35], Dentex dentex [36], Argyrosomus regius [37], Epinephelus septemfasciatus [38] or Dicentrarchus labrax [39].

The objective of the present study was to chart the ossification of the vertebral column, dorsal, anal and caudal fin complex in S. rivoliana larvae cultured under semi intensive system conditions (mesocosms, [8]). Larvae culture under this type of system usually performed better than those cultures under intensive conditions [32]. The identification of bony structures and mineralization pattern will serve as a tool for future studies, where different factors (zootechnical, nutritional, environmental parameters, etc) may affect the apparition of skeletal abnormalities.

\section{Material and Methods}

S. rivoliana eggs were obtained from induced spawning (hormonally injection, GnRHa; Sigma-Aldrich ${ }^{\mathrm{TM}}$ ), based on the reported dosage [8] Larvae were reared under mesocosms rearing system (4.5 eggs. $\mathrm{l}^{-1}$ in two $40 \mathrm{~m}^{3}$ tanks [8]), kept under natural photoperiod and filtered natural sea water with $37 \mathrm{~g} / \mathrm{L}$ salinity and temperature of $23.0 \pm 0.9^{\circ} \mathrm{C}$. Green water technique was used adding live phytoplankton (Nannochloropsis sp.) to maintain a concentration of 250000 cells ml-1 in the rearing tanks. From 2 to 25 days after hatching (dah) rotifers, Brachionus sp., L-strain enriched with DHA Protein Selco (INVE ${ }^{\mathrm{TM}}$ ), were added twice a day (08:00 and 14:00 h). Artemia feeding starts at $15 \mathrm{dah}$, and were enriched with A1 Easy Selco (INVE ${ }^{\mathrm{TM}}$ ). Weaning protocol included manual feeding from 20 dah (Genma Micro, Skretting ${ }^{\mathrm{TM}}$ ) to 25 dah and automatic feeding afterwards.

Larval growth was assessed measuring the standard length (SL) of 25 larvae, every 2 days using a profile projector (Nikon V-12A, NIKON $\left.{ }^{\mathrm{TM}}\right)$. A total of 75 specimens were individually stained (3.28 $\pm 0.15-16.1 \pm 0.89 \mathrm{~mm} \mathrm{SL})$. To study the bone ossification, all specimens were fixed in $10 \%$ buffered formalin, from hatching to 33dah. Fixed larvae were cleared and stained with alizarin red [40]. Larvae were individually examined using stereomicroscopy. Drawings of the different developmental stages were made using the Adobe Photoshop CS3-10.0 (1990-2007 Adobe System Incorporated, United States) directly from digital photographs. Bone description, followed the terminology suggested by different authors [41-43], and their abbreviations, and are illustrated in the Table 1 . The angles of the spine

*Corresponding author: Mesa-Rodríguez A, Aquaculture Research Group, Science and Technology Park, University of Las Palmas de Gran Canaria, P. O. Box 56, 35200 Telde, Canary Islands, Spain, Tel: 0034928132900; Fax: 0034928132908; E-mail: a.mesa.rodriguez@gmail.com

Received July 28, 2014; Accepted September 12, 2014; Published September 22, 2014

Citation: Mesa-Rodríguez A, Hernández-Cruz CM, Socorro JA, Fernández Palacios H, Izquierdo MS, et al. (2014) Skeletal Development and Mineralization Pattern of the Vertebral Column, Dorsal, Anal and Caudal Fin Complex in Seriola Rivoliana (Valenciennes, 1833) Larvae. J Aquac Res Development 5: 266. doi:10.4172/2155-9546.1000266

Copyright: () 2014 Mesa-Rodríguez A, et al. This is an open-access article distributed under the terms of the Creative Commons Attribution License, which permits unrestricted use, distribution, and reproduction in any medium, provided the original author and source are credited. 
Citation: Mesa-Rodríguez A, Hernández-Cruz CM, Socorro JA, Fernández-Palacios H, Izquierdo MS, et al. (2014) Skeletal Development and Mineralization Pattern of the Vertebral Column, Dorsal, Anal and Caudal Fin Complex in Seriola Rivoliana (Valenciennes, 1833) Larvae. J Aquac Res Development 5: 266. doi:10.4172/2155-9546.1000266

Page 2 of 6

\begin{tabular}{|c|c|c|}
\hline Region & Skeletal elements & Abbreviations \\
\hline \multirow[t]{14}{*}{ Vertebral Column } & Vertebra centra & $\mathrm{Ce}$ \\
\hline & Notochord & No \\
\hline & Urostyle & Ur \\
\hline & Neural Arch & $\mathrm{Na}$ \\
\hline & Neural Spine & Ns \\
\hline & Haemal Arch & $\mathrm{Ha}$ \\
\hline & Haemal Spine & $\mathrm{Hs}$ \\
\hline & Dorsal Ribs & $\mathrm{Eb}$ \\
\hline & Pleural Ribs & Plr \\
\hline & Parapophyses & $\mathrm{Pp}$ \\
\hline & Anterior neural zygapophysis & Anz \\
\hline & Posterior neural zygapophysis & Pnz \\
\hline & Anterior haemal zygapophysis & Ahz \\
\hline & Posterior haemal zygapophysis & Phz \\
\hline \multirow[t]{6}{*}{ Caudal Fin } & Hypurals & Hy \\
\hline & Parhypural & $\mathrm{Ph}$ \\
\hline & Epurals & Ep \\
\hline & Uroneurals & Un \\
\hline & Caudal lepidotrichia & PCR \\
\hline & Caudal Dermatotrichia & SCR \\
\hline \multirow[t]{5}{*}{ Dorsal Fin } & Predorsal & $\mathrm{Pd}$ \\
\hline & Hard Spines & $\mathrm{S}$ \\
\hline & Lepidotrichium & $\mathrm{R}$ \\
\hline & Proximal Pterygiophores & $\operatorname{Pr}$ \\
\hline & Distal Radial & $\mathrm{Dr}$ \\
\hline \multirow[t]{4}{*}{ Anal Fin } & Hard Spines & $\mathrm{S}$ \\
\hline & Lepidotrichium & $\mathrm{R}$ \\
\hline & Proximal Pterygiophores & $\operatorname{Pr}$ \\
\hline & Distal Radial & $\mathrm{Dr}$ \\
\hline
\end{tabular}

Table 1: Skeletal elements and their abbreviations.

were measured from the beginning of the vertebral body to the tip of the spine.

A total of $10 \mathrm{~S}$. rivoliana reared juveniles were soft X-ray monitored (Mod. Senographer-DHR, General electric's, USA) for meristic counts.

\section{Results}

\section{Vertebral column}

In the present study, $S$. rivoliana vertebral column mineralization was initiated with the neural arches $\left(\mathrm{Na}_{1}-\mathrm{Na}_{3}\right)$ by $4.40 \pm 0.14 \mathrm{~mm} \mathrm{SL}$ (Figure 1A), followed by the haemal arches $\left(\mathrm{Ha}_{1}-\mathrm{Ha}_{3}\right)$ and the cephalic vertebrae $\left(\mathrm{Ce}_{1-4}\right)$ by $4.74 \pm 0.27 \mathrm{~mm} \mathrm{SL}$ (Figure $\left.1 \mathrm{~B}\right)$. The ossification of the vertebral column followed a cranial-caudal direction, being totally ossified by $11.82 \pm 0.4 \mathrm{~mm} \mathrm{SL}$ (Figure 1G). This size marked the end of metamorphosis. The notochord flexion was initiated at 5.12 $\pm 0.11 \mathrm{~mm}$ SL (Figure 1C), at the same time that the caudal complex mineralization was initiated. Initially, urostyle was formed by two independent structures $\left(\mathrm{Ur}_{1}-\mathrm{Ur}_{2}\right)$ that fused by $10.23 \pm 0.26 \mathrm{~mm} \mathrm{SL}$ (Figure $1 \mathrm{~F})$. The neural spine $\left(\mathrm{Ns}_{23}\right)$, the haemal spine $\left(\mathrm{Hs}_{13}\right)$ and the $\mathrm{Ce}_{22}-\mathrm{Ce}_{23}$ were the last structures that mineralized. At $11.82 \pm 0.4 \mathrm{~mm}$ SL (Figure $1 \mathrm{G}$ ), four types of articulation processes were mineralized: anterior neural zygapophyses (Anz), posterior neural zygapophyses $(\mathrm{Pnz})$, anterior haemal zygapophyses (Ahz) and posterior haemal zygapophyses (Phz), (Figure 1G).

The vertebral bodies mineralization in the cephalic (without parapophyses) and prehaemal (with parapophyses) region $\left(\mathrm{Ce}_{1-4}\right.$ and $\mathrm{Ce}_{5-10}$ respectively) proceeded from dorsal to ventral direction and from the surface to internal bone layers (Figures 2A and 2B), whereas in the haemal (with $\mathrm{Hs}$ ) and caudal region (Ns and Hs modified to support caudal fin complex) the mineralization pattern proceeds in both directions dorsal and ventrally $\left(\mathrm{Ce}_{11-21}\right.$ and $\mathrm{Ce}_{22-23}$ respectively), joining in the middle of the centra (Figure 2C). Exceptionally, in $\mathrm{Ce}_{9}$ and $\mathrm{Ce}_{10}$, the mineralization of the vertebral bodies differed from other vertebral structures of the prehaemal region, proceeding dorsally first and ventrally later on.

The $\mathrm{Na}$ and $\mathrm{Ha}$ developed from centrum and fused in the middle, forming the neural and haemal canals with rounded shape, later developing into the Ns and Hs (Figures 2A-2C). The Ns and Hs angle in relation to the vertebral body varied along the vertebral column, increasing in cranial-caudal direction (Figure 1G). The Hs developed according to the angle of the first anal pterygiophore, and decreasing afterward.

The parapophyses $(\mathrm{Pp})$ was first observed with the mineralization

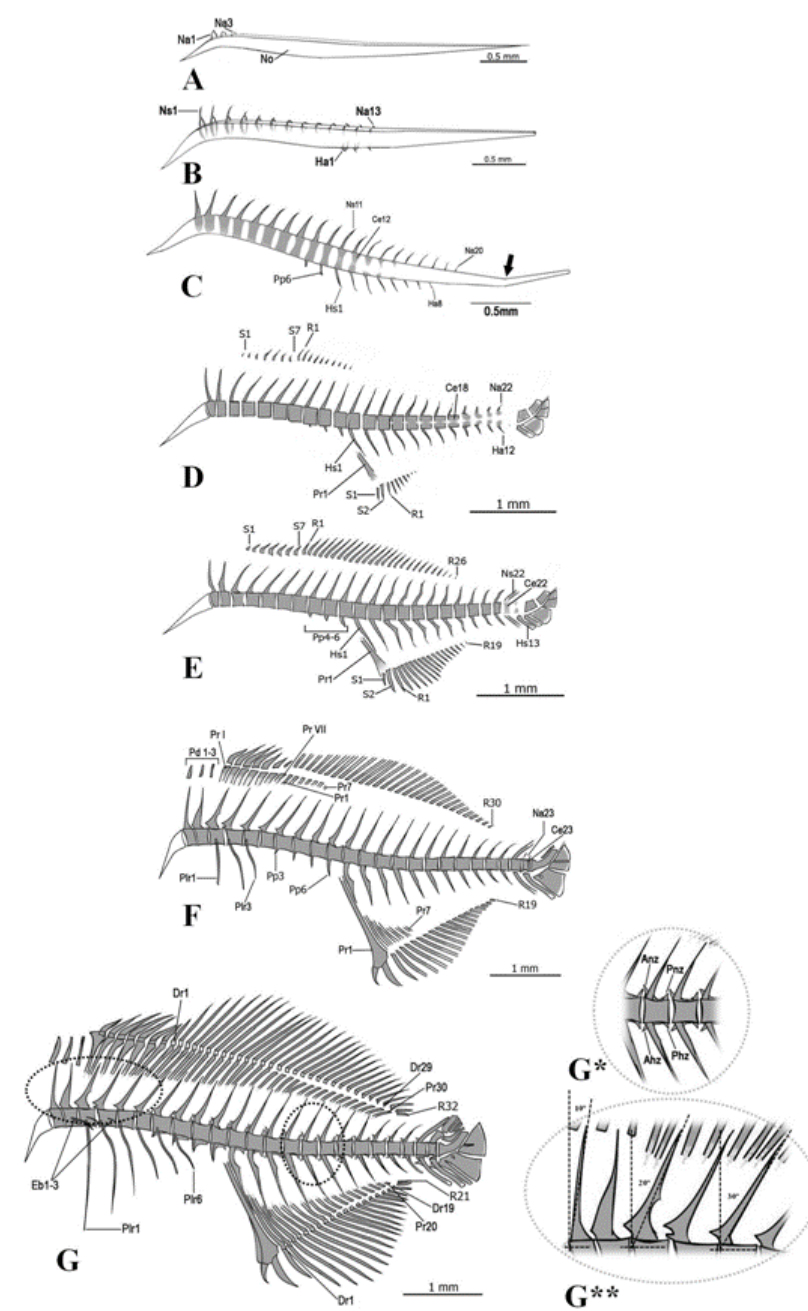

Figure 1: Development of the vertebral column (A - G) in S. rivoliana (painted areas, mineralized structures). Structures: Ahz, anterior haemal zygapophysis; Anz, anterior neural zygapophysis; Ha, haemal arch; Hs, haemal spine; No, notochord; $\mathrm{Na}$, neural arch; Ns, neural spine; $\mathrm{Pp}$, parapophyse; Plr, pleural rib; Pd, predorsal; Ph, parhypural; Phz, posterior haemal zygapophysis; Pnz, posterior neural zygapophysis; Pr, proximal pterygiophore; R, lepidotrichium $\mathrm{Dr}$, distal radial; $\mathrm{S}$, hard spine; $\mathrm{Ce}$, vertebral centra; Ur, urostyle. 
Citation: Mesa-Rodríguez A, Hernández-Cruz CM, Socorro JA, Fernández-Palacios H, Izquierdo MS, et al. (2014) Skeletal Development and Mineralization Pattern of the Vertebral Column, Dorsal, Anal and Caudal Fin Complex in Seriola Rivoliana (Valenciennes, 1833) Larvae. J Aquac Res Development 5: 266. doi:10.4172/2155-9546.1000266

Page 3 of 6

\begin{tabular}{|c|c|c|c|c|c|c|c|c|c|c|c|c|c|c|c|c|c|c|c|c|c|c|c|c|}
\hline \multirow[t]{3}{*}{ Species } & \multicolumn{23}{|c|}{ Regions } & \multirow[t]{2}{*}{ References } \\
\hline & \multicolumn{7}{|c|}{ Vertebral column } & \multicolumn{6}{|c|}{ Caudal fin } & \multicolumn{6}{|c|}{ Dorsal Fin } & \multicolumn{4}{|c|}{ Anal Fin } & \\
\hline & 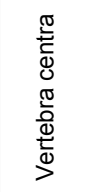 & $\begin{array}{l}\frac{0}{2} \\
\text { 怘 } \\
\text { 잏 }\end{array}$ & $\begin{array}{l}\frac{0}{\frac{1}{0}} \\
\frac{0}{0} \\
\frac{\pi}{0} \\
\frac{0}{2} \\
\frac{0}{2}\end{array}$ & 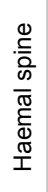 & 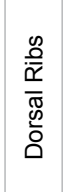 & $\begin{array}{l}\frac{\infty}{0} \\
\frac{0}{\square} \\
\frac{\pi}{\square} \\
\frac{0}{\square}\end{array}$ & 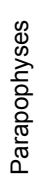 & 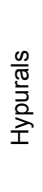 & 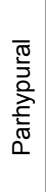 & 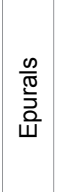 & $\begin{array}{l}\frac{\infty}{\pi} \\
\frac{0}{5} \\
0 \\
\frac{1}{0} \\
\frac{0}{J}\end{array}$ & $\begin{array}{l}\frac{\pi}{2} \\
\frac{0}{0} \\
\frac{0}{0} \\
.0 \\
00 \\
0 \\
0\end{array}$ & $\begin{array}{l}\frac{\pi}{\frac{\pi}{0}} \\
\frac{0}{0} \\
\frac{0}{0} \\
\frac{0}{0} \\
\frac{E}{0} \\
0\end{array}$ & 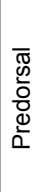 & 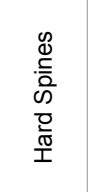 & 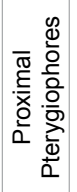 & 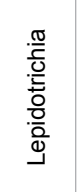 & 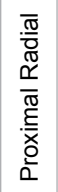 & 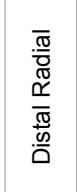 & 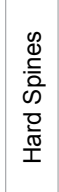 & $\begin{array}{l}\frac{\pi}{2} \\
\frac{0}{0} \\
\frac{0}{2} \\
.00 \\
\frac{0}{0} \\
0\end{array}$ & 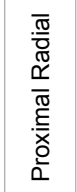 & 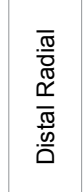 & \\
\hline S. rivoliana & $10+13$ & $1+1$ & 23 & 13 & $6+6$ & $8+8$ & 6 & 5 & 1 & 3 & $1+1$ & $10+9$ & $10+9$ & 3 & VII+I & 7 & $30 / 34$ & $\begin{array}{l}30 / \\
34\end{array}$ & $30 / 34$ & $\mid I+1$ & $19 / 21$ & $19 / 22$ & $19 / 22$ & $\begin{array}{l}\text { Present } \\
\text { Study }\end{array}$ \\
\hline S. dumerili & $10+13$ & $1+1$ & 23 & 13 & $6+6$ & $8+8$ & 6 & 5 & 1 & 3 & $1+1$ & $9+9$ & $12+10$ & 3 & VII-VIII & $\begin{array}{l}\text { 08- } \\
\text { Jul }\end{array}$ & $31 / 34$ & 35 & 32 & III & $19 / 21$ & $20 / 23$ & $20 / 23$ & [28] \\
\hline S. fasciata & - & - & - & - & - & - & - & - & - & - & - & - & - & - & VIII+I & - & $28 / 31$ & - & - & $11+1$ & $18 / 20$ & - & - & {$[60]$} \\
\hline C. crysos & - & $1+1$ & - & - & - & - & - & 5 & 1 & 3 & $1+1$ & - & - & - & - & - & - & - & - & - & - & - & - & {$[44]$} \\
\hline S. fasciata & - & - & - & - & - & - & - & - & - & - & - & - & - & - & VIII+I & - & $28 / 31$ & - & - & $I I+I$ & $18 / 20$ & - & - & [61] \\
\hline S. rivoliana & - & - & - & - & - & - & - & - & - & - & - & - & - & - & $\mathrm{VII+I}$ & - & 30 & - & - & $11+1$ & 21 & - & - & [62] \\
\hline S. rivoliana & - & - & - & - & - & - & - & - & - & - & - & - & - & - & $\mathrm{VII+I}$ & - & 32 & - & - & $11+1$ & 22 & - & - & [63] \\
\hline S. dumerili & $10+13$ & 1 & 22 & 13 & - & $8+8$ & - & 5 & 1 & 3 & $1+1$ & $9+7$ & $12+11$ & 3 & VII-VIII & & $31 / 32$ & 38 & - & II-III & 20 & 21 & - & [27] \\
\hline S. lalandi & - & $1+1+1$ & - & - & - & - & - & 5 & 1 & $\begin{array}{c}\text { 04- } \\
\text { Mar }\end{array}$ & $1+1$ & - & - & - & - & - & - & - & - & - & - & - & - & [29] \\
\hline S. setapinnis & $10+14$ & - & 24 & 14 & - & - & - & 5 & 1 & - & - & $9+8$ & $5+6$ & - & - & - & - & - & - & - & - & - & - & {$[45]$} \\
\hline H. amblyrhynchus & $10+14$ & - & 24 & 14 & - & - & - & - & - & - & - & $9+9$ & $8+8$ & - & $\mathrm{VII+I}$ & - & 28 & - & - & $11+1$ & 25 & - & - & {$[55]$} \\
\hline T. japonicus & $10+14$ & 1 & 24 & 14 & $7+7$ & $10+10$ & 6 & 5 & 1 & 2 & 1 & 17 & - & 3 & 8 & 8 & $\begin{array}{l}27 / \\
35\end{array}$ & $\begin{array}{c}27 / \\
35\end{array}$ & $\begin{array}{c}27 / \\
35\end{array}$ & $\mid I+I$ & $\begin{array}{c}25 / \\
31\end{array}$ & $\begin{array}{c}25 / \\
31\end{array}$ & $\begin{array}{c}25 / \\
31\end{array}$ & [43] \\
\hline
\end{tabular}

Table 2: Meristic counts in different carangid species. ( - ) no data; ( + ) and; ( / ) between.

of the $\mathrm{Pp}_{6}-\mathrm{Pp}_{5}$ by $5.12 \pm 0.11 \mathrm{~mm} \mathrm{SL}$ (Figure 1C). These structures had a caudal-cranial development and were fully ossified at $11.82 \pm 0.4 \mathrm{~mm}$ SL (Figure 1G). The Pp structures become larger form $\mathrm{Ce}_{4}$ to $\mathrm{Ce}_{10}$.

The pleural ribs (Plr) were observed for the first time at $10.23 \pm 0.26$ $\mathrm{mm} \mathrm{SL}\left(\mathrm{Plr}_{1}-\mathrm{Plr}_{3}\right)$ with the caudal development (Figure 1F). $\mathrm{Plr}_{4}-\mathrm{Plr}_{7}$ developed at $11.82 \pm 0.4 \mathrm{~mm}$ SL (Figure $1 \mathrm{G}$ ). The dorsal ribs $(\mathrm{Eb}$ ) were first seen at $11.82 \pm 0.4 \mathrm{~mm} \mathrm{SL}$ (Figure $1 \mathrm{G}$ ), with the mineralization of the $\mathrm{Eb}_{1}-\mathrm{Eb}_{3}$, following the caudal development.

\section{Dorsal and anal fins development}

The formation and mineralization of the dorsal and anal fins of the long fin yellowtail followed a cranial-caudal direction. The first dorsal fin structures were the hard spines (S) and lepidotrichium (R) by 8.01 $\pm 0.26 \mathrm{~mm} \mathrm{SL}$ (Figure 1D), which initiated its mineralization from the base to the tip of the structure. Predorsal bones $\left(\mathrm{Pd}_{1}-\mathrm{Pd}_{3}\right)$ and proximal pterygiophore $(\mathrm{Pr})$ had a dorsal-ventral mineralization pattern (Figure $1 \mathrm{~F})$.

In the anal fin, the two hard spines $\left(\mathrm{S}_{1}-\mathrm{S}_{2}\right)$ were first seen at $8.01 \pm$ $0.26 \mathrm{~mm}$ SL (Figure 1D), same as the anal lepidotrichia (R) and Pr. The $\mathrm{S}_{1}-\mathrm{S}_{2}$ fused into the Pr1 by $9.92 \pm 0.84 \mathrm{~mm}$ SL (Figure $1 \mathrm{E}$ ). The $\mathrm{S}_{1}-\mathrm{S}_{2}$ and $\mathrm{R}$ mineralized from the base to the tip of the structure, whereas the $\mathrm{Pr}$ followed a ventral-dorsal pattern (Figure 1F).

\section{Caudal fin development}

The first caudal complex structures in mineralized were the upper and lower caudal lepidotrichia (PCR) by $5.12 \pm 0.11 \mathrm{~mm} \mathrm{SL}$ (Figure 3A). Then, hypurals (Hy) initiated their mineralization as fused structures, first $\mathrm{Hy}_{1}+\mathrm{Hy}_{2}$, continues with $\mathrm{Hy}_{3}+\mathrm{Hy}_{4}$ and finally parhypural (Ph) by $5.38 \pm 0.11 \mathrm{~mm} \mathrm{SL}$ (Figure 3B). At the same time, the first upper caudal dermatotrichia (SCR) started to mineralize, following a base-tip mineralization pattern. The last hypural $\left(\mathrm{Hy}_{5}\right)$ delayed its mineralization to $8.01 \pm 0.26 \mathrm{SL}$ (Figure 3C). By $9.92 \pm 0.84$ $\mathrm{mm}$ SL uroneurals $\left(\mathrm{Un}_{1}+\mathrm{Un}_{2}\right)$ arted to mineralize and fused forming a single structure (Uroneural) (Figures $3 \mathrm{D}$ and $3 \mathrm{E}$ ). Finally, the last
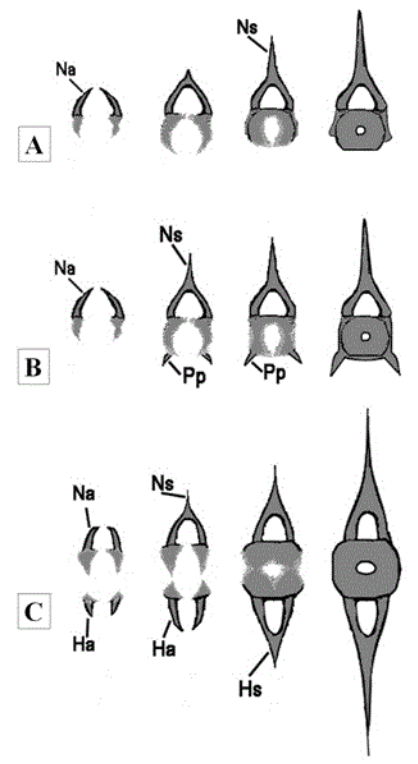

Figure 2: Vertebra mineralization (A-C) (painted areas, mineralized structures) $\mathrm{Ha}$, haemal arch; Hs, haemal spine; $\mathrm{Na}$, neural arch; Ns, neural spine; Pp, parapophyses.

caudal complex structures in mineralized were the epurals $\left(\mathrm{Ep}_{1-3}\right)$ by $11.82 \pm 0.4 \mathrm{~mm}$ SL (Figure 3E).

\section{Meristic characters}

Meristically, S. rivoliana had a total number of 23 vertebrae (urostyle not included), 23 neural spines, 13 haemal spines, 16 pleural ribs, 12 dorsal ribs and 6 parapophyses. In the dorsal region, 3 predorsal spines, VII+I hard spines and a variable number (30-34) lepidotrichia were identified. Besides, VII hard spine proximal pterygiophores, 30 to 34 distal radial and proximal pterygiophores were also observed. 
Citation: Mesa-Rodríguez A, Hernández-Cruz CM, Socorro JA, Fernández-Palacios H, Izquierdo MS, et al. (2014) Skeletal Development and Mineralization Pattern of the Vertebral Column, Dorsal, Anal and Caudal Fin Complex in Seriola Rivoliana (Valenciennes, 1833) Larvae. J Aquac Res Development 5: 266. doi:10.4172/2155-9546.1000266

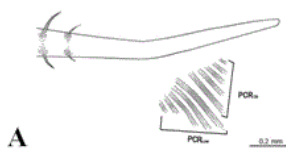

A

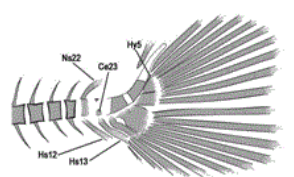

C
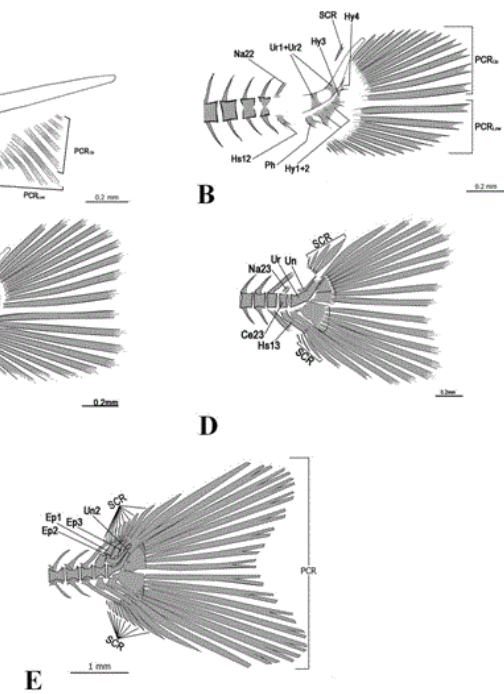

B

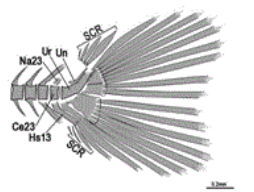

Figure 3: Development of S. rivoliana caudal complex (A-E) (painted areas, mineralized structures). Structures: Ep, epurals; Hy, hypurals; PCR, caudal lepidotrichia; Ph, parhypural; SCR, caudal dermatotrichia; Ur, urostyle; Un uroneural.

Within the anal region, II+I hard spines and 19-21 lepidotrichia, same number of distal radial and proximal pterygiophores were identified. Finally, in the caudal complex, 1 parahypural, 5 hypurals, 3 epurals, 2 uroneurals, $10+9$ caudal lepidotrichia and $10+9$ caudad dermatotrichia were observed (Table 2).

\section{Discussion}

This study reported for first time S. rivoliana skeletal development and mineralization. The comparison of present results with other species from the same family and genus, such as $S$. dumerili, suggest some correspondence. Thus, [27] describes first mineralized structure in the vertebra centra for $S$. dumerilli at $6.6 \mathrm{~mm}(\mathrm{NL})$ while other result for the same specie [28] identified Neural Spine (NS) and centra at $4.8 \mathrm{~mm}(\mathrm{TL})$. This pattern agrees with present data for S. rivoliana, where similar mineralization was obtained $(4.74 \pm 0.27 \mathrm{~mm} \mathrm{SL})$. The differences between vertebra centra mineralization timing for $S$. dumerili could be explained by the different environmental conditions, such as temperature, or rearing protocols applied in those studies [32]. In fact, mineralization pattern is more accurately described when larval growth is used as reference instead of larval age [33].

Also, the present study showed a similar vertebra centra mineralization timing in comparison with other carangid species, such as Caranx crysos [44] and Selene setapinnis [45,46], suggesting that some developmental events during mineralization process may be common for many species. For instance, the dorsal flexion at the posterior end of the notochord could be an external indicator of the initiation of the internal column mineralization for this and other species. In fact, these events also occur in other species such as $S$. aurata larvae $(5.7-6.0 \mathrm{~mm}$, SL) [30], Solea senegalensis larvae (4.7 mm, SL) [35], Pagrus pagrus larvae (6.0 $\pm 0.5 \mathrm{~mm}, \mathrm{TL})$ [32] or Argyrosomus regius larvae (5.42-6.01 $\mathrm{mm}, \mathrm{TL})$ [47].

In most Perciforms, the vertebral column follows a bidirectional mineralization pattern (Pagrus major, [42]; S. aurata, [30]; Dentex dentex, [36]; Diplodus sargus, [47]; Pagrus pagrus, [32]). However, in S. rivoliana the vertebral column followed a unidirectional mineralization pattern, in agreement with data reported in S. dumerili [28] and in A. regius [46].

According to the centrum mineral deposition, three complementary models occur in the vertebral region: in a dorsal-ventral direction (D-V), in a ventral-dorsal direction (V-D) or simultaneously (DVS). In $S$. aurata [30] and D. sargus [47], two centra mineral deposition models occur the first one takes place in a $\mathrm{D}-\mathrm{V}$ direction from the $\mathrm{Ce}$ to $\mathrm{Ce}_{21}$ and the second one in a V-D direction in $\mathrm{Ce}_{22}$ and $\mathrm{Ce}_{23}$. In $S$. rivoliana, the mineralization expands in a $\mathrm{D}-\mathrm{V}$ direction from $\mathrm{Ce}_{1}$ to $\mathrm{Ce}_{23}$, following the same pattern as $\mathrm{S}$. dumerili between the $\mathrm{Ce}_{1}-\mathrm{Ce}_{19}$ [28]. Additionally, S. rivoliana had simultaneously DVS mineralization from $\mathrm{Ce}_{8}$ to $\mathrm{Ce}_{23}$, whereas $S$. dumerili [28] presents this simultaneous DVS mineralization pattern from $\mathrm{Ce}_{20}$ to $\mathrm{Ce}_{23}$. Other marine finfish such as $A$. regius [47] showed a D-V mineral deposition from $\mathrm{Ce}_{1}-\mathrm{Ce}_{4}$, while the remaining vertebrae had simultaneous DVS mineralization.

About to urostyle (Ur) structure of $S$. rivoliana larvae and other marine finfish such as P. major, C. crysos and S. dumerili $[28,44,48]$, this was formed by the fusion of two elements $\left(\mathrm{Ur}_{1}+\mathrm{Ur}_{2}\right)$. In contrast, at least three elements were necessary to form this structure in $S$. lalandi [29]. The results of the present study suggest that the fusion of different structures to form the urostyle is nonspecific of the genus Seriola sp.

The development of the parapophyses $(\mathrm{Pp})$ of $S$. rivoliana followed a caudal-cranial development, in concordance with $S$. dumerili [28] and many other perciforms such as $S$. aurata [30], Lates calcarifer [49], Diplodus sargus [47] or Pagrus pagrus [32]. The correlation between the present study and many other marine finfish suggest that the developmental patter for the parapophyses may be common in perciforms [49].

In many marine finfish species, the mineralization of the anal and posterior dorsal fins starts prior to the anterior dorsal fin [31,32,50-52]. Unlike this developmental pattern, but in accordance with $S$. dumerili [28], S. rivoliana dorsal and anal structures followed a cranial-caudal development, developing the anterior dorsal fin prior to posterior dorsal fin. However, despite S. rivoliana and S. dumerili had the same developmental pattern in dorsal, anal and caudal fins; some differences in structures development have been observed. For instance, in $S$. rivoliana, firsts structures in mineralized were hard spines $(S)$ and lepidotrichium (R) (present study), whereas in S. dumerili [28] the dorsal fins development starts with the mineralization of the proximal pterygiophore.

During the process of the caudal complex mineralization of $S$. rivoliana, the fusion of hypurals $\left(\mathrm{Hy}_{1}+\mathrm{Hy}_{2}\right.$ and $\left.\mathrm{Hy}_{3}+\mathrm{Hy}_{4}\right)$ was observed. This developmental pattern is common in other carangid species such as S. lalandi [29], S. setapinnis [47], C. crysos [44] and S. dumerili $[27,28]$; as well as other perciforms such as Coryphaena equiselis [53], P. major [42], S. aurata [30] and D. dentex [36]. The development of three distinct structures $\left(\mathrm{Hy}_{1}+\mathrm{Hy}_{2}, \mathrm{Hy}_{3}+\mathrm{Hy}_{4}, \mathrm{Hy}_{5}\right)$ could remain as a characteristic of carangids and Coryphaena [44].

In the present study, the development of three epurals and two uroneurals were observed. The number of epurals in the caudal complex of Carangoidei species varies between species [44]: 3 epurals in S. dumerili [28], between 3-4 epurals (usually 3 epurals) in S. lalandi [29], 2 independent epurals that fused during ontogeny in C. equiselis [53] and 3 epurals for S. rivoliana (present study). Other authors [54] considered that the presence of uroneurals is a characteristic of the Teleost. The presence of two uroneurals in S. rivoliana caudal fin complex is in concordance with other species from the same genus 
Citation: Mesa-Rodríguez A, Hernández-Cruz CM, Socorro JA, Fernández-Palacios H, Izquierdo MS, et al. (2014) Skeletal Development and Mineralization Pattern of the Vertebral Column, Dorsal, Anal and Caudal Fin Complex in Seriola Rivoliana (Valenciennes, 1833) Larvae. J Aquac Res Development 5: 266. doi:10.4172/2155-9546.1000266

such as S. lalandi [29] and S. dumerili [28].

Meristically, the vertebral column of longfin yellowtail (S. rivoliana) was characterized in this study. Similar results have been reported in S. dumerili [28]. Nevertheless, in other carangid species such as S. setapinnis [45], Hemicaranx amblyrhynchus [55] or Trachurus japonicas [43] a total number of 24 vertebral structures were observed, and the first haemal arch was observed at the $10^{\text {th }}$ vertebra [45] instead of at the $11^{\text {th }}$ vertebrae in $S$. dumerili $[27,28]$ and $S$. rivoliana (present study), indicating that this could be a conserved feature among the genus Seriola (Table 2).

Concerning the caudal complex, S. rivoliana presented similar results than those observed in S. lalandi [29], S. setapinnis [45], C. crysos [44] and S. dumerili [27,28], although the number of caudal fin rays is a characteristic for each species. Thus, in this study, S. rivoliana had $10+9$ caudal lepidotrichia and $10+9$ caudad dermatotrichia, while $9+9$ caudal lepidotrichia and 11-13+10 caudal dermatotrichia where reported in $S$. dumerili [28] or $9+8$ caudal lepidotrichia and $6+5$ caudad dermatotrichia were observed in S. setapinnis [45].

The importance of the meristic characterization is widely known for the identification not only for marine finfish species, [56,57] but also in cultured fish species [52,58,59].

Results from the present study might be used as practical guide for future studies on this field with S. rivoliana or in related species.

\section{Acknowledgement}

This study was funded by the Agencia Canaria de Investigación, Innovación y Sociedad de la Información (ACIISI) and Fondo Europeo de Desarrollo Regional (FEDER) through the program "Mejora de las técnicas de cría de larvas de (Seriola rivoliana): Determinación de requerimientos de ácidos grasos esenciales en su etapa larvaria y optimización de la secuencia alimentaria (METCSERProlD20100094)".

\section{References}

1. Mazzola A, Favaloro E, Sará G (2000) Cultivation of the Mediterranean amberjack, Seriola dumerili (Risso, 1810), in submerged cages in the Western Mediterranean Sea. Aquaculture 181: 257-268.

2. Jerez S, Samper M, Santamaría FJ, Villamandos JE, Cejas JR, et al. (2006) Natural spawning of greater amberjack (Seriola dumerili) kept in captivity in the Canary Islands. Aquaculture 252: 199-207.

3. Sims NA, Key G (2011) Fish without footprints. Oceans 11-MTS, IEEE Kona, $1-6$

4. Benetti DD (1997) Spawning and larval husbandry of flounder (Paralichthys woolmani) and Pacific yellowtail (Seriola mazatlana), new candidate species for aquaculture. Aquaculture 155: 307-318

5. Blacio E, Darquea J, Rodríguez S (2003) Advances in Growing Huayaipe, Seriola Rivoliana (Valeciennes 1833) Facilities In Cenaim. El mundo acuícola 9: $21-24$

6. Blacio EM (2004) Outdoor tank culture of almaco jacks in Ecuador. Global Aquaculture Advocate, USA.

7. Laidley CW, Shields RJ, Ostrowksi AO (2004) Amberjack sulture Progress at Oceanic Institute in Hawaii, Glob Aqua Advoc 7: 42-43.

8. Roo J, Fernández-Palacios $\mathrm{H}$, Hernández-Cruz CM, Mesa-Rodriguez A Schuchardt D, et al. (2012) First results of spawning and larval rearing of longfin yellowtail Seriola rivoliana as a fast-growing candidate for European marine finfish aquaculture diversification. Aquaculture Research 45: 689-700.

9. Benetti DD (2000) Aquaculture of Pelagic Marine Fish: I. Yellowtail amberjacks (S. quinqueradiata, S. lalandi, S. dumerili and S. mazatlana). Global Aquaculture Advocate 20.

10. Garcia-Gomez A (2000) Recent advances in nutritional aspects of Seriola dumerili. Paper presented at: Recent advances in Mediterranean aquaculture finfish species diversification. Zaragoza: CIHEAM-IAMZ 47: 249-257.
11. Poortenaar CW, Hooker SH, Sharp N (2001) Assessment of yellowtail kingfish (Seriola lalandi) reproductive physiology, as a basis for aquaculture development. Aquaculture 201: 271-286.

12. Nakada M (2002) Yellowtail culture development and solutions for the future. Reviews in Fisheries Science 10: 559-575.

13. Cobcroft JM, Psnkhurst PM, Poortenaar C, Hickman B, Tait M (2004) Jaw malformation in cultured yellowtail kinfish (Seriola lalandi) larvae. New Zealand Journal of Marine and Freshwater Research 38: 67-71.

14. Tomas A, de la Gandara F, Garcia-Gomez A, Perez L, Jover M (2005) Utilization of soybean meal as an alternative protein source in the Mediterranean yellowtail, Seriola dumerili. Aquaculture Nutrition 11: 333-340.

15. Takakuwa F, Fukada H, Hosokawa H, Masumoto T (2006) Optimum digestible protein and energy levels and ratio for greater amberjack Seriola dumerili (Risso) fingerling. Aquaculture Research 37: 1532-1539.

16. Papadakis IE, Chatzifotis S, Divanach P, Kentouri M (2007) Weaning of greate amberjack (Seriola dumerilii Risso 1810) juveniles from moist to dry pellet. Aquaculture International 16: 13-25

17. Hamasaki K, Tsuruoka K, Teruya K, Hashimoto H, Hamada K, et al. (2009) Feeding habits of hatchery-reared larvae of greater amberjack Seriola dumerili. Aquaculture 288: 216-225.

18. Marino G, Mandich A, Massari A, Andaloro F, Porrello S (1995a) Aspects of reproductive biology of the Mediterranean amberjack (Seriola dumerilii Risso, 1810): Gonadal development7: 115-124.

19. Marino G, Mandich A, Massari A, Andaloro F, Porrello S, et al. (1995b) Aspects of reproductive biology of the Mediterranean amberjack (Seriola dumerilii Risso) during spawning period. Journal of Applied Ichthyology 11: 9-24.

20. Kozul V, Skaramuca B, Glamuzina B, Clavic N, Tutman P (2001a) Comparative gonadogenesis and hormonal induction of spawning of cultured and wild mediterranean amberjack (Seriola dumerili Risso 1810). Scientia Marina 65 215-220.

21. Mylonas CC, Papandroulakis N, Smboukis A, Papadaki M, Divanach P (2004) Induction of spawning of cultured greater amberjack (Seriola dumerili) using GnRHa implants. Aquaculture 237: 141-154.

22. Lazzari A, Barbera G (1989) Farming the Mediterranean yellowtail, Seriola dumerilii (Risso, 1810) in concrete ponds: results and perspectives. Belgium: European Aquaculture Society 209-213

23. Porrello S, Andaloro F, Vivona P, Marino G (1993) Rearing trial of Seriola dumerili in a floating cage. Production, Enviromental and Quality. Bordeaux Aquaculture '92. European Aquaculture Society Special Publication 18: 299 307

24. Muraccioli P, de La Gandara F, Garcia-Gomez A (2000) Intensive farming potential of Seriola dumerilii (Risso 1810) in Corsica. Paper presented at: Recent advances in Mediterranean aquaculture finfish species diversification,Spain.

25. Papandroulakis N, Mylonas CC, Maingot E, Divanach P (2005) First results of greater amberjack (Seriola dumerili) larval rearing in mesocosm. Aquaculture 250: $151-161$

26. Cobcroft JM, Battaglene SC (2013) Skeletal malformations in Australian marine finfish hatcheries. Aquaculture 396: 51-58.

27. Liu CH (2001) Early osteologycal development of the yellow tail Seriola dumerili (Pisces: Carangidae). Zoological Studies 40: 289-298.

28. Laggis A, Sfakianakis DG, Divanach P, Kentouri M (2010) Ontogeny of the body skeleton in Seriola dumerili (Riso, 1810). Italian Journal of Zoology 77: 303315

29. Kohno H (1997) Osteological development of the caudal skeleton in the carangid, Seriola lalandi. Ichthyological Research 44: 219-221.

30. Faustino M, Power DM (1998) Development of osteological structures in the sea bream: Vertebral column and caudal fin complex. Journal of Fish Biology 52: 11-22.

31. Faustino M, Power DM (1999) Development of the pectoral, pelvic, dorsal and anal fins in cultured sea bream. J Fish Biol 54: 1094-1110.

32. Roo J, Socorro J, Izquierdo MS (2010a) Effect of rearing techniques on skeletal deformities and osteological development in red porgy Pagrus pagrus (Linnaeus, 1758) larvae. J Appl Ichthyol 26: 372-376. 
Citation: Mesa-Rodríguez A, Hernández-Cruz CM, Socorro JA, Fernández-Palacios H, Izquierdo MS, et al. (2014) Skeletal Development and Mineralization Pattern of the Vertebral Column, Dorsal, Anal and Caudal Fin Complex in Seriola Rivoliana (Valenciennes, 1833) Larvae. J Aquac Res Development 5: 266. doi:10.4172/2155-9546.1000266

33. Roo FJ, Hernández-Cruz CM, Socorro JA, Fernández-Palacios $\mathrm{H}$, Izquierdo MS (2010b) Occurrence of skeletal deformities and osteological development in red porgy Pagrus pagrus larvae cultured under different rearing techniques. J Fish Biol 77: 1309-1324.

34. Gavaia PJ, Dinis MT, Cancela ML (2000) Skeletal development as an assessment criteria for larval Solea senegalensis (Kaup) quality. Eur Aquacult Soc Spec Publication 28: 233.

35. Gavaia PJ, Dinis MT, Cancela ML (2002) Osteological development and abnormalities of the vertebral column and caudal skeleton in larval and juvenile stages of hatchery-reared Senegal sole (Solea senegalensis). Aquaculture 211: 305-323.

36. Koumoundouros G, Divanach P, Kentouri M (1999) Osteological development of the vertebral column and of the caudal complex in Dentex dentex. J Fish Biol 54: 424-436.

37. Fernández-Palacios $H$, Schuchardt $D$, Roo J, Borrero $C$, Hernández-Cruz $C M$ et al. (2007) Estudio morfométrico de la corvina (Argyrosomus regius, 1801) durante el primer mes de vida. Actas XI Congreso Nacional de Acuicultura 755758

38. Boglione C, Marino G, Giganti M, Longobardi A, De Marzi P, et al. (2009) Skeletal anomalies in dusky grouper Epinephelus marginatus (Lowe 1834) juveniles reared with different methodologies and larval densities. Aquaculture 291: 48-60.

39. Koumoundouros G, Maingot E, Divanach P, Kentouri M (2001a) Kyphosis in reared sea bass (Dicentrarchus labrax): ontogeny and effects on mortality. Aquaculture 209: 49-58.

40. Vandewalle P, Gluckmann I, Wagemans F (1998) A critical assessment of the alcian blue/alizarin double staining in fish larvae and fry. Belgian Journal of Zoology 128: 93-95.

41. Manod T (1968) Le complexe urophore des poisons téléostéens. Mém Inst Fr Afr Noire 81: 1-705

42. Matsuoka M (1987) Development of the skeletal tissues and skeletal muscles in red sea bream. Bulletin of Seikai Regional Fisheries Research Laboratory 65: $1-114$

43. Suda Y (1996) Osteology and muscular attachments of the Japanese Jack Mackerel, Trachurus japonicus. Bulletin of Marine Science 58: 438-493.

44. Hilton EJ, Johnson GD (2007) when two equals three: developmental osteology and homology of the caudal skeleton in carangid fishes (Perciformes: Carangidae). Evol Dev 9: 178-189.

45. Katsuragawa M (1997) Larval development of the Atlantic Moonfish Selene setapinnis (Osteichthyses, Carangidae) from southeastern Brazil. Bulletin of Marine Science 61: 779-789.

46. Cardeira J, Valle R, Dionísio G, Estévez A, Gisbert E, et al. (2012) Osteology of the axial and appendicular skeletons of the meagre Argyrosomus regius (Sciaenidae) and early skeletal development at two rearing facilities. J Appl Ichthyol 28: 464-470.

47. Koumoundouros G, Sfakianakis DG, Maingot E, Divanach P, Kentouri M (2001b) Osteological development of the vertebral column and of the fins in Diplodus sargus (Teleostei: Perciformes: Sparidae). Marine Biology 139: 853862

48. Kohno H, Taki $Y$ (1983) Comments on the development of fin-supports in Fishes. Japanese Journal of Ichthyology 30: 284-290

49. Fraser MR, Anderson TA, de Nys R (2004) Ontogenic development of the spine and spinal deformities in larval barramundi (Lates calcarifer) culture. Aquaculture 242: 697-711.

50. Koumoundouros G, Divanach P, Kentouri M (2001c) Osteological development of Dentex dentex (Osteichthyes, Sparidae): Dorsal, anal, paired fins and squamation. Marine Biology 138: 399-406.
51. Sfakianakis DG, Koumoundouros G, Divanach P Kentouri M (2004) Osteological development of the vertebral column and of the fins in Pagellus erythrinus (L. 1758). Temperature effect on the developmental plasticity and morphoanatomical abnormalities Aquaculture 232: 407-424

52. Sfakianakis DG, Doxa CK, Kouttouki S, Koumoundouros G, Maingot E, et al (2005) Osteological development of the vertebral column and of the fins in Diplodus puntazzo (Cetti, 1777). Aquaculture 250: 36-46.

53. Potthoff $T$ (1980) Development and structure of fins and fin supports in dolphin fishes Coryphaena hippurus and Coryphaena equiselis (Coryphaenidae). Fish Bull 78: 277-312.

54. Lauder G, Liem KF (1983) The evolution and interrelationships of the Actinopterygian fishes. Bulletin of the Museum of Comparative Zoology, Harvard University 150: 95-197.

55. Flores-Coto C, Sánchez-Ramírez M, Zavala-García F (1998) Morfología externa del desarrollo larvario de Hemicaranx amblyrhynchus (Pisces: Carangidae) del sur del Golfo de México. Rev biol trop 46.

56. Turan C (2004) Stock identification of Mediterranean horse mackerel (Trachurus mediterraneus) using morphometric and meristic characters. ICES Journal of Marine Science 61:774-781.

57. Turan C, Oral M, Ozturk B, Duzgunes E (2006) Morphometric and meristic variation between stocks of bluefish (Pomatomus saltatrix) in the Black, Marmara, Aegean and northeastern Mediterranean seas. Fisheries Research 79: 139-147.

58. Ferreri F, Nicolais C, Boglione C, Bertolini B (2000) Skeletal characterization of wild and reared zebrafish: anomalies and meristic characters. J Fish Biol 56: 1115-1128.

59. Boglione C, Costa C, Di Dato P, Ferzini G, Scardi M, et al. (2003). Skeletal quality assessment of reared and wild sharpsnout sea bream and pandora juveniles. Aquaculture 227:373-394.

60. Bañón R Mucientes GR (2009) First record of Seriola fasciata (Carangidae) from Galician waters (NW Spain). A new northernmost occurrence in the NE Atlantic. Cybium 33: 247-248.

61. Andaloro F, Falautano M, Sinopoli M, Passarelli FM, Pipitone C, et al. (2005) The lesser amberjack Seriola fasciata (Perciformes: Carangidae) in the Mediterranean: A recent colonist?. Cybium 29: 141-145.

62. Castriota L, Falautano M, Greco S, Andaloro F (2004) Second record of Seriola rivoliana (Carangidae) in the Mediterranean. Cybium 28: 265-266.

63. Castriota L, Greco S, Marino G, Andaloro F (2002) First record of Seriola rivoliana Cuvier, 1833 (Osteichthyes: Carangidae) in the Mediterranean. J Fish 